\title{
HISTORICAL SOCIOLOGY OF THE JAMAICAN CHURCH-FOUNDED FREE VILLAGE SYSTEM
}

Three related themes are treated in this paper. Firstly, an attempt is made to sketch in the historical background of the rise of a peasantry in Jamaica, British West Indies, at the time of the Emancipation. Secondly, data are provided on the foundation and growth of a particular Jamaican freedmen's village, Sturge Town, founded by the Baptists in the parish of St. Ann. Lastly, the sociological character of the church-founded free villages is established on the basis of what is known of their founding and growth. *

THE BACKGROUND OF FREE VILLAGE SETTLEMENT

IN J I.A.M.AICA

The Caribbean islands were the first outposts of European colonialism in the New World, but their economic importance was not realized until the plantation system came into full flower there in the eighteenth century. Since that time, though slavery is long past and the character of the plantation as an agro-social institution has been completely transformed, though the islands which were once the richest possessions of the Western European powers are now overshadowed in importance by other tropical areas, it is still the plantation system for which the Caribbean area is known.

Plantations, particularly sugar plantations, are a predominant feature of the landscape in Puerto Rico, Cuba, and the Dominican Republic; they are vital parts of the economies of Jamaica,

* The author owes thanks to Professor John V. Murra of Vassar College, and to Dr. Michael G. Smith of the Institute of Social and Economic Research, University College of the West Indies, for valuable help and advice in the preparation of this paper. 
Guadeloupe and Barbados; and they are important even in the smaller islands as well. But alongside the plantations in many of these same islands, or more frequently in their rugged interiors, are large numbers of peasant farms, usually very small in size, and usually unprogressive in the character of the agriculture employed on them, yet of great significance culturally and economically. With the exception of those islands lost by Spain in I899, and those too small or too lately occupied ever to have developed a full-scale plantation system, the peasantry is a relatively recent social product, a population reconstituted into a new economic form during the decline and fall of the slavebased estate system. In an important article in which he seeks to delineate the characteristics of the peasantries of Latin America, Dr. Eric Wolf has set the Caribbean peasant peoples within a separate typological category. This category, he writes:

... is perhaps best represented by peasants located in a region which once formed a key area of the developing system of capitalism. This region is located in the seasonally rainy tropical lowlands of northeastern Brazil and the West Indies. Here sugar plantations based on slave labor flourished in the sixteenth, seventeenth, and eighteenth centuries. These plantations were weakened by a variety of factors, such as the end of the slave trade and the political independence movement in Latin America, and most of them were unable to compete with other tropical areas. Where the old plantation system was not replaced by modern 'factories in the field,' as has been the case in northeastern Brazil and on parts of the south coast of Puerto Rico, we today find peasant holdings as 'residual bits' of former large scale organizations which have disintegrated, as in Haiti and Jamaica. The economy of such areas has been contracting since the end of slavery, with the result that this type of peasant seems to lean heavily toward the production of subsistence crops for home use or toward the production and distribution of very small amounts of cash produce. ${ }^{1}$

Wolf makes clear that, except for special instances, Caribbean peasants represent a secondary development within the islands. In the case of Jamaica, Philip M. Sherlock has referred to the "strange and absorbing story of how, out of the social rubble inherited in 1837 a resilient people began to create its own New World". ${ }^{2}$ These peasantries, then, represent a transformation of one kind of laboring population into another, a historical process which varied in character from one island or territory to another, and from one colonial system to another. Its study has but barely begun. ${ }^{3}$ The enslavement, transportation and reemployment of literally millions of African people over more than four centuries was the most dramatic instance of forced acculturation 
in human history; the creation of free and independent peasantries out of these ex-slaves is no less dramatic and in all ways more inspiring.

Final and complete emancipation within the British colonies in the New World, declared effective on August I, I838, freed approximately $3 \mathrm{II}, 000$ persons in Jamaica alone. ${ }^{4} \mathrm{It}$ was assumed by most observers, except the planters themselves, that these new freedmen, over 218,000 of whom had been 'praedial' (that is, field) slaves, ${ }^{5}$ would continue to serve as the labor base for the plantation system. Joseph Sturge, the famous English Quaker abolitionist, predicted that:

In a state of freedom it may be expected that the conditions and resources of an agricultural labourer, working for regulated wages, will be, as they are in England, superior to those of a paltry agriculturist, cultivating his little plot of land with his own hands; and it is evident therefore that the negroes will generally prefer working on the estates. Their strong attachment to the place of their birth, to their houses and gardens, to the graves of their parents and kindred, exceeding what has been recorded of any other people, is another circumstance which favours their continuance as labourers on the estates to which they are now respectively attached. 6

But Sturge did not take sufficient account of the vindictiveness of the planters, of their own relatively desperate economic situation, or of the legitimate and very intense desire of the freedman to establish himself as a yeoman farmer. ${ }^{7}$

In Jamaica, the independent peasantry came into being almost entirely after Emancipation. Under the leadership of Baptist, Methodist and other missionaries, who had worked fearlessly for Emancipation itself - once they realized that their missionary labors with the slaves had become impossible in the face of planter resistance - the Jamaican freedman got his clearest opportunity to become a peasant cultivator. The process had a curiously unpremeditated and undeliberate character at first. Punitive laws passed by the Jamaica Assembly, which was dominated in the post-Emancipation period by the planters, was leading to a powerful movement of ex-slaves off the estates. ${ }^{8}$ The pull of the independent homestead predated Emancipation, and some settlement of freedmen had already occurred. 9 But the trend became much stronger after freedom for all was enacted. In order for new freedmen to become independent farmers, certain conditions were necessary. First, they would have to be able to grow subsistence crops successfully. The skills for subsistence agriculture had been mastered by the slaves under 
slavery itself in Jamaica, since it was customary to compel the field slave to grow his own foodstuffs on unused estate land. 10 Second, the freedmen would require outlets for surplus which could be exchanged for cash to buy those things not within the individual's capacity to produce for himself, but already part of his consumption patterns. This condition had also been guaranteed by slavery itself in Jamaica, since slaves had been permitted, even encouraged, to market their surplus at island markets. ${ }^{11}$ These markets continued in strength after Emancipation, even increasing in number. ${ }^{12}$ Moreover, there grew up a brisk export trade in agricultural staples, many items formerly produced on estates becoming peasant products. Pre-Emancipation agricultural and marketing practices of the slaves were the major means by which the slaves could accumulate liquid capital, 13 and this capital formed the basis for the third condition the formation of a free peasantry would require: money with which to buy land. The availability of the land itself was the fourth essential condition for the growth of a peasant class. Land might be acquired simply by squatting on Crown property, and this occurred, though its importance in the total picture may have been exaggerated. ${ }^{14}$ Or land could be bought up by individual freedmen from the surplus of economically still viable estates or from ruined estates. Much buying of this kind took place, but it was not the most efficient or successful means for resettling freedmen as peasants. It was in this immediate postEmancipation period that the leaders of the Baptist and Methodist missionary churches hit upon the idea of buying up ruined estates in toto upon which they might resettle parishioners as independent peasants in church communities. This idea, which caught hold swiftly, and had a revolutionary effect upon Jamaican society, can be attributed mostly to the Baptist ministers William Knibb and James Phillippo. Rev. Phillippo had in fact founded a village for freedmen during the period of the Apprenticeship (I834-I838), and may be considered the originator of this scheme. ${ }^{15}$ But it was after Emancipation, when the pressures, both positive and negative, to get off the estates became irresistible, that the church-founded free village system floresced. Paget ${ }^{16}$ has provided the best brief summary of this movement. Between I 838 and I844, a period of six years, I9,000 freedmen and their families removed themselves from the estates, bought land, and settled in free villages. In terms of the total population affected, this figure may represent an aggregate of as much as West-Indische Gids XXXVIII 
I00,000 persons. The initial transformation of ex-slaves into independent yeomen farmers on a grand scale was accomplished in less than a decade. Its social and economic importance for the subsequent character of Jamaican society cannot be overestimated.

THE CHURCH-FOUNDED FREE VILLAGE OF STURGE TOWN, PARISH OF ST. ANN

The ministers Phillippo and Knibb, who initiated the free village movement, were followed by many others. The Reverends Burchell, Abbott, and John Clark were among these. It is Rev. John Clark who is of particular interest here. ${ }^{17}$ Clark came to Jamaica in 1835 to assist Rev. James Coultart at the Baptist Church at St. Ann's Bay on the north coast of Jamaica in the Parish of St. Ann. Rev. Coultart died in I836, and Rev. Clark moved thereupon to Brown's Town, in the highlands - called the Dry Harbour Mountain district - of the same parish. The St. Ann's Bay Church was delegated to another minister and Rev. Clark was charged with the church at Brown's Town, and with ministering to the needs of the Baptists in the surrounding district. The Apprenticeship system, instituted in 1834, was operative in those years. Rev. Clark, like many of his fellow ministers, noted and protested against abuses in this alleged gradual transition from slavery to freedom and played a role in the fight against its continuance. Ultimately, Emancipation was enacted two years before the Apprenticeship was originally to have been terminated. During this period Rev. Clark was in correspondence with Joseph Sturge, who had emerged as the leading abolitionist in Great Britain, since Clarkson was of advanced age and Wilberforce was dead. Once Emancipation was enacted, it was with the help of Sturge - who, it is to be remembered, had mistakenly believed that the slaves would remain resident on the estates after freedom - that Rev. Clark undertook to establish free villages under church sponsorship. Clark's influence in creating a peasantry in the Dry Harbour Mountains region of St. Ann was considerable. In the course of his work, he established or helped to establish a large number of free villages. From the impetus provided by church sponsorship, other free villages grew without the deliberate patronage of the missionary churches. Clark, in his report to Joseph Sturge, 18 states that over 20 free villages were founded in the Dry Harbour 


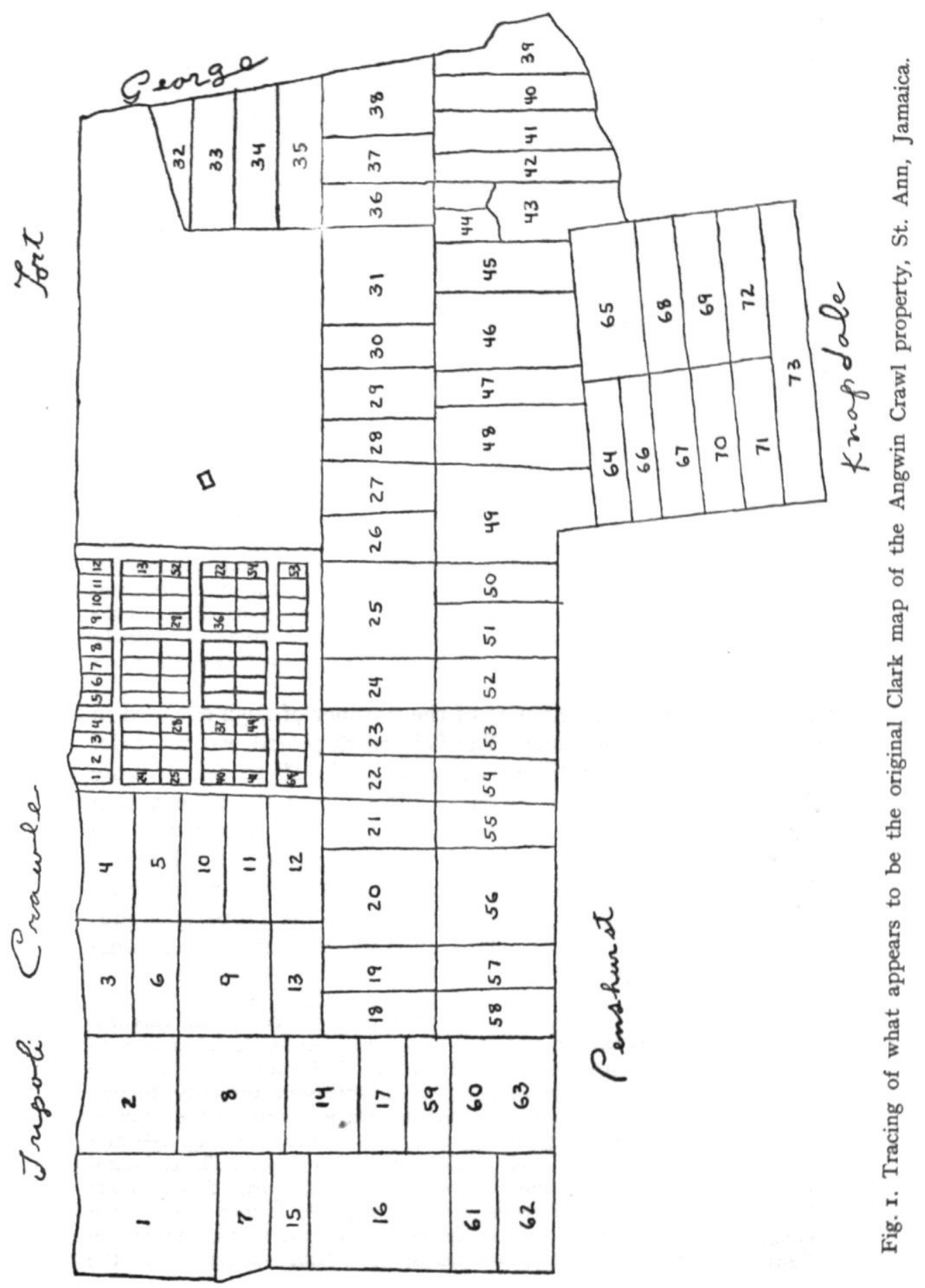


Mountains of St. Ann alone in the years immediately following Emancipation. They held fifteen or sixteen hundred families, about three-fourths of the enfranchised population of the district. 19 In the first three years of freedom, the peasantry connected with the Baptist churches of St. Ann Parish spent $£$ Io,00o for the purchase of land, 20 and Knibb claimed that up to I845, 43 free villages had been founded in that parish alone. ${ }^{21}$

According to Rev. Clark's testimony, the first free village founded under his sponsorship was Sturge Town. ${ }^{22}$ Rev. Clark describes that village specifically in his report to Joseph Sturge:

The first property I bought contained 120 acres of good land, about eight miles from Brown's Town. The cost, with expenses of conveyance and surveying was about $£ 700$ sterling. Of this amount rather more than $\ell 400$ was paid down by about eighty or ninety of the people, and the remainder by instalments and by additional purchasers. Nearly roo building lots, and an equal number of acres for provision grounds, were surveyed. Small neat cottages were speedily built, and the land brought into good cultivation. There was a house and two or three acres of land left clear after the whole cost was paid. The house was converted into a schoolroom, and placed in trust for the benefit of the villagers, who erected a large booth, as a temporary place of worship, capable of containing 400 or 500 people. A chapel and mission house have subsequently been built. The settlement was called Sturge Town (now Birmingham). ${ }^{23}$

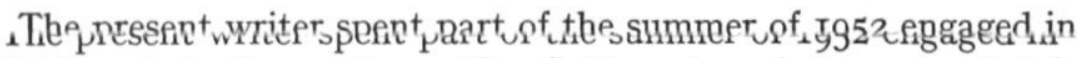
field work in Sturge Town. The field work period was too brief and too often interrupted by other obligations ${ }^{24}$ to permit more than sporadic collection of data, but some of the information gathered will be reported here. Of particular interest was the later discovery by the writer, in the map collection of the Jamaica Institute, of an original map which appears to be that made by or for Rev. John Clark after he purchased the property - previously named Angwin Crawl ${ }^{25}$ - upon which Sturge Town came to stand (Fig. I). ${ }^{26}$

In an examination of some hundreds of maps in the collection, this was the only one of its kind found, and it was the purest stroke of luck to have found it, since it was discovered after the field work period in Sturge Town. It is certain that this is indeed a map of the same property; though no name appears on the map, it corresponds in shape to the original property pictured on Jamaica cadastral maps of the area (Fig. 2) ${ }^{27}$ and the names of the contiguous properties correspond as well. The cadastral section carries both the names Angwin Crawl and Sturge Town on the holding; and old Sturge Towners reported that the former name of the village had been Angwin Crawl. According to Rev. Clark, the Sturge Town property contained ' 120 acres of good land'; according to the 


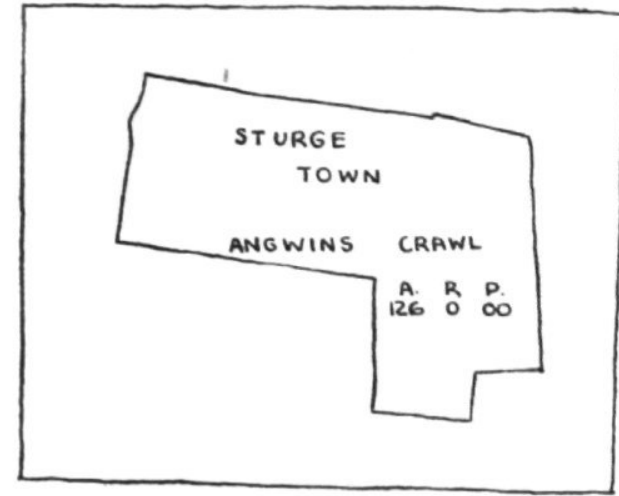

Fig. 2. Copy of the cadastral section showing the Angwin Crawl - Sturge Town property, St. Ann, Jamaica.

cadastral section and the deed of transfer, it contains $\mathbf{1 2 6}$ acres. The difference may be concealed in Rev. Clark's phrasing; it is not a significant difference in any case.

To judge by the appearance of the Clark map, it was drawn up at some point after the property had been purchased and surveyed, and some, but not all, of the holdings had been taken up by settlers. The arrangement of the house plots, the varying character of the agricultural plots, and certain other features of settlement as indicated on the map, raise questions concerning the original nature of this church-founded free village By tabulation, there are 74 individual agricultural holdings (of which 73 are numbered); 72 house plots (of which 27 are numbered); and a large, undefined plot greater in size than that of the total indicated housing area. Rev. Clark claimed that there were "nearly roo building lots, and an equal number of acres for provision ground" in the Sturge Town settlement when it was completed; though only 72 house plots are indicated on the map, later reference to the number of individuals buying lots makes it clear that the large plot east of the indicated housing area must have been subsequently subdivided into additional housing and farm holdings. If this were not the case, then the land in excess of 72 (or 73) agricultural holdings and the land needed for more than 72 houses would have remained in the hands of the church. Planimeter calculations, using 126 acres as the assumed total area of the property, indicate that the undefined plot east of the delineated housing area comes to 16.66 acres. Rev. Clark writes that "a house and two or three acres of land" were left clear after settlement, and this certainly would not square with the Clark map had there not been additional occupance of the undefined northeast lots. ${ }^{28}$

The 73 numbered agricultural plots are of particular interest since they vary significantly in size. The possible reasons for this are many; the writer can do no more at this point than indicate those which have occurred to him. Individual settlers may have acquired land in amounts in accordance with their capacity to pay, with some maximum perhaps being set by the church. Again, the size of the landholding purchased may have been determined relative to the size of the family of the purchaser. Or the holdings may have been staked out with regard for estimated variation in soil quality, topography, etc. - though this last seems unlikely, given the overall small size of the pro- 
perty. Lastly, there may have been some favoritism shown. The writer has been unable to recover evidence of any kind so far favoring one or another of these possible explanations. But it is at least possible that the original settlers varied in their economic status from the first, and this could be a sociological datum of primary importance. 29

From Rev. Clark's description of the founding of Sturge Town, and from descriptions of the community provided by later writers, it is possible to say something relatively specific concerning the sociology of this one church-founded free village. For instance, Clark's comments indicate that the majority of the original settlers were known to him personally, and that they were members of his church. Thus he describes 'eighty or ninety of the people' paying for their land while some land was paid for 'by additional purchasers'. This strongly suggests that Sturge Town was wholly or almost wholly a Baptist community from its very beginnings. I believe we can assume with fair assurance that all of the settlers in such a village were churchgoers, though this is admittedly speculative. The same sentence written by Clark indicates, of course, that the land was bought, not given to the settlers, and that some of it was paid off by installment. Since Clark specifies that the land, together with

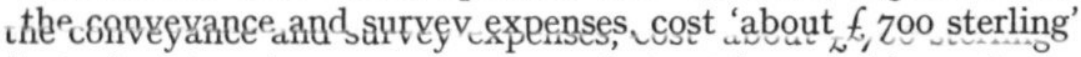
(but cf. note 23), we may assume that settlers could purchase their holdings for approximately $£ 7$ per acre. ${ }^{30}$ Though this price was not excessive at the time, the fact that some people paid off their obligations by installment indicates some degree of continuing financial control by the church, and of continuing financial obligation on the part of the settlers. ${ }^{31}$ From the subsequent description we learn that a school and a church were added to the community immediately upon its establishment. The school was run by the church. The church itself, according to Clark's letter, was staffed by a local minister, Mr. Samuel Hodges, who, at the time of Clark's writing, had been living in Sturge Town for 'the last seven or eight years'; 32 that is, from about 1843 or 1844 until I85I or I852. Not only did Sturge Town consist of a religiously homogeneous or nearhomogeneous group, but it had a church-run school and its own chapel and resident minister. That minister, or another, was there at the time of the visit of Candler and Alexander, who passed through Sturge Town in 1850 . The report of these visitors contains the following brief on Sturge Town: 
Population 54I; houses, wattled and shingled, ro3; wattled and thatched, 2; huts, 6; total of houses, III ; floor of apartments, boarded, 45; terraced, 163. Families, 113; parents, 228; children and unmarried persons, 313. Children who attend the day school, Ir2; Sabbath school, 200. Copies of the Scriptures, 187. Each house has its separate acre of land, where, in addition to provisions, pimento is frequently cultivated, and in some instances sugar-cane. There are also in the village some small wooden mills for grinding the cane, and on almost all the little properties some simple contrivance for expressing its juice. Such villages, built on the summit or slope of some fine hill, interspersed with bananas and plantains, and shaded by mangoes and breadfruit trees, have a very pleasing appearance, and greatly enliven the face of nature. The moral condition of Sturge Town is, we believe, superior to most that have not the advantage of a resident missionary. ${ }^{33}$

This description provides a little new information, some directly, and some which may be inferred. There has been a slight growth in population and an increase in the number of houses. Neolocal residence predominates (II3 families, III houses). Crop diversification seems strong, but the quotation is naive in this regard. Pimento, a tree crop, is not 'cultivated' but spread wholly through the agency of nature. It is a traditional export crop in Jamaica, and was probably sold for export by Sturge Town people. Other tree crops mentioned are mangoes and breadfruit. Surpluses of these foods were probably sold as well for distribution in the island markets, as they are today. Cultivation of sugar cane in an area wholly unfitted for it is a common persistence in the Caribbean, and rural people often prefer the crude brown 'moscovado' sugar to refined white sugar. The presence of small wooden mills is almost certain evidence of production for sale. The internal marketing system grew rapidly in Jamaica after Emancipation, as did peasant production of export crops and products, such as pimento, beeswax, annatto, fustic, logwood, and honey. Production for sale was a major means of acquiring money for the purchase of land, after Emancipation, as well as before.

The family-parent figures indicate family stability. Differences in house type and flooring do not suggest significant economic differentiation, but the description is too thin and brief to help much in this regard.

Rev. Clark's letter cited earlier must have been written some time after the visit of Candler and Alexander. While stressing the success of the free village movement, Rev. Clark indicates that the fervency and piety of the people was waning at the time he wrote. The villagers, he says, 
... should be aided for a few years to maintain their religious and educational institutions ... [because] at the present time they are unable, in consequence of the reduction of wages, frequent want of employment, distress arising from the ravages of cholera and small pox, and heavy taxation, to contribute more than one third of the amount they once cheerfully gave towards building chapels and school houses and supporting their pastors and teachers. There are also not a few who do not sufficiently value religious and educational advantages to make sacrifices to obtain them. ${ }^{34}$

Rev. Clark's concern for the villagers in church-founded settlements was realistic. In spite of the influence the missionary churches might wield over the free settlements, there might be tendencies toward either a decline of religiosity on the one hand, or toward the growth of a 'folk' variety of Christianity on the other. Curtin has assembled evidence that a folk version of Christianity, with emphasis on leading of the spirit, possession, and ideological synthesis with elements of African religions, even predated the development of organized missionary churches in Jamaica. ${ }^{35}$ In some instances, organized churches were subtly changed in character to bring their doctrines and practices more into line with obeahism and myalism, religious forms originating at least in part in the African tradition. The final firsthand report the present writer was able to locate, in the form of abbreviated notes made by Underhill, makes mention of just such a change in Sturge Town:

STURGE TOWN TABERNACLE. Rev. John Clark, pastor. Number of members, 107. (It is necessary to mention that this church is a secession from the church under the native minister, Mr. McLaggan, and arose out of certain occurrences connected with Obeahism, in which the minister and some of the members were involved). 'We are a handful of corn'. Have no fault to find as to attendance; attendance 'most beautiful', except it be wet and sloppy in the town. The classes in the town are pretty well attended. There are about 700 persons in Sturge Town; all attend either the Tabernacle or Mr. McLaggan's. The Sunday School is very good; but some of the teachers come late. Very few backsliders; but they attend chapel regularly. The leaders are very attentive to their duty and look after the 'slack'. If you scold the people, you make them worse. There are many complaints about the estates. People are not getting rid of religion, though it is not as it was twenty years ago. A little before and after freedom there was more piety, everybody 'was going to chapel', All felt the yoke of Satan, and looked to religion for comfort then. Young people 'feel no lash'; yet they are coming to chapel; but do not exhibit such great piety. There is not so much religion now as before the cholera. People do not feel so much now as at the time when 'free come'. There was not so much trouble in admitting members then as now, piety was more apparent, there was no need to examine so strictly. Some deacons and 
leaders hesitate now to recommend for membership any who are not married people. Young people can earn money for themselves, and are not so dependent on the old people; they do not listen as formerly to the old people 'to tick to de gospel'. 36

This final description comes about 20 years after the founding of Sturge Town. ${ }^{37}$ It suggests that, while the Baptist church still wielded considerable influence in the village, new forces had arisen which were causing change in various ways - by providing competing faiths; by enabling the young to earn money independent of their families; by preventing a careful and exact perpetuation of the original ideology of the free village through the children of the settlers. Yet even Underhill's rather pessimistic picture still conveys the idea of a largely homogeneous church community. People still attend church regularly; the outbreak of Obeahism (which Sturge Towners in 1952 know about from hearsay, but could not detail, since it occurred over a century before) had been quelled and services were back to normal; the "leaders are attentive to their duty and look after 'the slack'."

No written reports on Sturge Town after I86I are known to the writer. ${ }^{38}$ But in 1952, when it was possible to spend a brief time in that community, certain continuities from the past were still visible. There were still two churches, both non-Established, and the Baptist Church was the larger and its congregation bigger. The Baptist Church still held some land, operated for its own support. The school was still operated by this church. The lay leaders of the Baptist Church included most of the richer landholders in the community - though none of these men would be considered wealthy by United States standards. (The biggest landholder in Sturge Town in I952, so far as could be determined, held I6 acres of land.) The Baptist Church was still the center of social and recreational activities, as well as the leading religious organisation. When a new teacher moved to the community, he immediately became involved in Baptist Church activities, though not himself a Baptist. One young local girl, upon beginning her practice teaching in the village, shifted her membership from the competing church to the Baptist Church. Opportunities for technical education and higher education generally seemed to be most accessible through the Baptist Church, though it must be emphasized that membership in a different church did not stand in the way of the Baptist minister's giving all possible help to a young person. The community had produced several outstanding Jamaican leaders during its history, 
in the fields of education and religion. In short, though the writer's data are much too limited to allow any elaborate conclusions, it was apparent that the founding church was still playing a central role in the life of the village and its residents in 1952. Further field work in this village is necessary to evaluate much more precisely the importance of the founding institution, over roo years after Sturge Town became a peasant community.

THE SOCIOLOGY OF THE CHURCH-FOUNDED

JAMAICAN FREE VILLAGE

If the church-founded free villages initially shared a large number of general sociological characteristics such that they might be considered to form a 'community type', the question is immediately raised whether such villages today are more like each other in their sociology than they are like other Jamaican villages with differing histories. To try to answer such a question immediately would be premature. But it is justifiable to seek these characteristics which may have been general to this kind of village at the time of founding.

Cumper is the first recent writer to call particular attention to the need for examining these villages to see whether they may

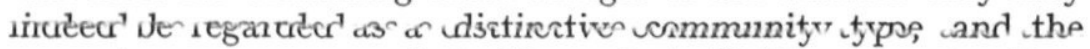
present paper owes much to his analysis. ${ }^{39}$ The present writer essays a speculative description of such villages at the time of their establishment in hopes of perhaps advancing Cumper's treatment somewhat further.

A summation of the expectable sociological characteristics of the churchfounded free village, related to the role of the church in maintaining a historically distinctive type of community subculture, might read as follows:

I. It was a geographically definable community

2. It was a socially definable community

3. It was wholly or largely a religiously homogeneous community, at least initially

4. Its population was differentiated in certain sociological regards from the freedman population as a whole;

a) more literate

b) more tied to organized Christian churches

c) more thrifty

d) composed of stable monogamous families

e) dependent upon and indebted to the missionary church 
5. It was isolated:

a) geographically in many cases

b) ideologically, initially, and perhaps for some time

6. It was under relatively strong church control due to:
a) financial obligations
b) pressures exerted by co-religionist neighbors
c) the influence and power of church leaders
d) difficulties of securing land outside the community
e) control of schools by the church

7. This church influence had good chances of perpetuation due to:

a) continued geographical isolation, in many cases

b) the church's role as a funnel for outside opportunities (missionary training, opportunities based on preliminary education, local restriction of economic opportunities)

c) likelihood of village (or at least intra-faith) endogamy, due to geographical isolation, church-sponsored recreation, parental and neighborly influence, etc.

The geographically definable character of the original churchfounded free villages is of great importance for the nature of their later development. Cohen $\mathbf{4 0}^{0}$ has described his difficulties in delimiting the rural community which he studied in Jamaica; and in a recent paper, M. G. Smith makes the point that the contemporary rural Jamaican community must be defined according to a set of variables such as topography, patterns of mating and visiting, etc., rather than by equating 'community' and 'village'. ${ }^{41}$ The need for sophisticated techniques to delineate the social boundaries of the modern Jamaican community arises because of the way such communities were established or the way they have grown up over time. Particularly where these settlements bordered large towns, or developed in areas within which they might expand by successive small-scale purchases of land, the borders of the villages have become difficult to specify. But the original free villages, unless they were founded near or within the confines of existing towns, were indeed geographcially definable as communities. We know this because of the way they were established: that is, through the purchase of a whole large estate, in the midst of other such estates, which was then subdivided among settlếrs. ${ }^{42}$

In the case of Sturge Town, even today it is geographically definable in these terms. It has indeed extended itself through purchase by some residents of adjacent land, and through the creation of a Land Settlement community (Thatchfield) on another estate bordering it. But it does not present the picture of 
continuous and extended settlement in many directions and seemingly, according to no preconceived order, so characteristic of many other Jamaican communities. Such free villages, then, were not congeries of scattered homesteads, but artificially created nuclei of population, with a particular internal social structure.

Every such free village, at least in the case of those founded under church sponsorship, was composed at the start of practicing co-religionists in good standing. While every single newly-settled freedman in a given village might not have been of the same faith, Rev. Clark's testimony and that of other missionary leaders of the time makes it clear that church-founded free villages were religiously homogeneous as well as geographically and socially definable communities.

It seems fair to argue that the populations of the churchfounded free villages differed to some degree from the freedman population as a whole. In all likelihood they were more literate, Bible-reading having been an important practice and educational objective for missionary congregations. Moreover the village inhabitants were probably more uniform in their attachment to an organized religion than the population as a whole. The people doubtless varied in their sincerity and fervency, and surely the missionaries must have been deceived at times by parishioners whose motives were not wholly pious. Yet the descriptions provided us make it likely that these villagers took their religious affiliation seriously for the most part.

Probably - one might better say possibly - the settlers as a group were more thrifty and industrious than other freedmen. This may be an unsupportable speculation. Yet those who acquired land first in the church-founded free villages were the savers, who had managed to lay something by during the Apprenticeship or before, and they were the members in good standing of the churches. Thrift of itself may be of little importance in the present context. What is important is the degree to which we may be allowed to speculate that the villagers in the church-founded free villages shared an ideology based on church membership and acceptance of its Christian tenets, particularly thrift, industry, and those other precepts associated with 'uprighthness' and humility. Lay church leaders in Sturge Town in 1952 were exemplary in these regards; most of them were relatively well-to-do peasants, and extremely hard workers. Significantly, the village itself enjoys a reputation among the middle 
JAMAICAN CHURCH-FOUNDED FREE VILLAGE SYSTEM 6I

class of the whole parish as a place where the best-mannered people of the rural class, and the best domestic workers, come from.

Cumper ${ }^{43}$ has pointed out that such free villages would consist in the beginning of populations composed of monogamous families. This point is of first importance, and one which would distinguish such populations from the freedman population as a whole. The writer's I952 census data for Sturge Town are insufficiently complete to indicate whether the village differs significantly in this regard from figures for the parish or for Jamaica as a whole; but that is the impression the incomplete data make.

The church-founded free village people had entered into a relationship of obligation to their churches when they first settled. This circumstance emerges as perhaps the most important of all in considering the present-day character of such villages, and will be treated in detail at a later point.

These villages were usually isolated geographically at the time of their founding, as pointed out earlier. In the case of St. Ann, it is true for many other such villages besides Sturge Town. Geographical isolation can serve as a powerful bar to culture change, of course. But isolation is not a function of geography alone. Smith writes:

Plantation economies and social systems have persisted on the plains, while peasant type economies and societies were developed among the population which settled the hills as squatters, freeholders, or with Mission assistance. One often finds today a general denominational attachment in some of these hill communities, and to some extent this attachment reflects the historical conditions in which Missions assisted their establishment. But today, church influence is probably dominant and integrating only where the community is considerably isolated. ${ }^{44}$

The writer grants that this may be the case. Sturge Town is indeed an example of a community where geographical isolation has persisted. But ideological or social isolation may persist even where geographical isolation has declined. And certain kinds of contacts with the outside may serve to strengthen existing patterns, rather than to weaken them. The sociological and anthropological literature is full of descriptions of part-societies which have retained cultural distinctiveness and social isolation even in strongly urban contexts or in situations of repeated and intense contact. The marketing pattern of many Sturge Town women, which takes them regularly out of the community and 
even to Kingston, has probably served to maintain cultural stability rather than to provoke change, since it allows villagers to conserve culturally approved standards of consumption which are very old and not rapidly expanding. The regular visits of Baptist ministers for Sunday services, wherein the community is 'penetrated', are not sources of change so much as a powerful force for conservatism and retention of old habits. Accessibility to change, therefore, cannot be viewed simply along an isolationcontact polarity, but must be seen rather in terms of the character of contact and its effect on people, and in terms of the strength of existing forces for cohesion and conservatism within the community.

At the time of their establishment, the church-founded free villages were under relatively strong missionary control. Individuals were surrounded by neighbors who were also coreligionists and probably often kinfolk as well. This suggests that internal pressures for conformance were present. Lay church leaders could exert influence in maintaining such conformances; they continue to do so in Sturge Town today. The way this control may operate can be illustrated by reference to the problem of accessibility to land. It was usually difficult to get access to additional land outside but conveniently near the free villages, and growing population meant inevitably that pressures for land would arise unless people emigrated. In the case of Sturge Town, additional holdings were gradually acquired by rental or rarely, purchase, from adjoining estates. But the scarcity of small holder land in general came to mean that those short of land would either have to walk great distances to their fields or to leave the community entirely. In one case recorded in I952, a Sturge Towner walked 22 miles each time he went to his fields, which he rented. He was anxious to acquire the right to work a piece of church property in Sturge Town. But he was not a faithful member of the local church. He did not get the use of the land. To what extent such incidents may have been important in earlier Sturge Town history cannot be established. 45 The lack of economic alternatives in such communities may have confronted the land-hungry villager with three alternatives: leave the community entirely; invest an unusual effort in obtaining a source of income far from the community while maintaining residence; or conform carefully to all social rules within the community in the hope of finding some economic niche within it. It is not intended to suggest here that the church exercised any 
JAMAICAN CHURCH-FOUNDED FREE VILLAGE SYSTEM 63

deliberate policy of exacting conformance from villagers through special economic controls. Even had this been the intent, the church's village resources would have been much too limited to have made this possible. Rather, conformance on the part of villagers might be expected to have existed quite incidental to local social and economic lines of power. ${ }^{46}$

Control of local schools is also relevant to making an estimate of the church's total influence. Schooling in a country such as Jamaica is the sine qua non of economic and social advancement. While the non-Established church schools are not used as instruments of indoctrination in the writer's opinion, villagers tend almost naturally to think of the school and church together. A student's future success is bound up with his early education, and the impression he makes upon his superiors in school. The fact that the schools in the church-founded free villages are usually tied to church supervision even today is hence of great importance in understanding the social structure of such villages.

These various circumstances, related to the sociology of the villages at the time of their founding, were perpetuated in varying strength in the following century. We begin with a picture of geographical isolation; a definable community social structure; a religiously homogeneous community; a village population sociologically distinguishable from the free population as a whole; financial and moral indebtedness to the founder's church; church control of the school; internal pressures for conformance exerted by lay leaders and neighbors; external pressures for conformance exerted incidentally by the church itself; and an absence of alternative economic opportunities of all kinds for local people. To the extent that such initial characteristics were perpetuated, we may assume the local community tended to maintain its original character. This is, of course, a circular statement, because much more needs to be known of the degree to which Sturge Town and communities like it have indeed remained as they were. The schools continue to be church-supervised in many cases. The lay leaders of the church continue to be community leaders - the larger landholders, the teachers, and the political workers. In the beginnfng, the missionary churches created upon the social landscape of Jamaica a large number of religiously homogeneous communities, frequently isolated physically from the larger society, isolated to some extent as well from competing faiths, and providing settings for their own perpetuation. The missionary-created peasant villages had a population 
which might be viewed as a distinctive subculture; to some extent, they may still have it. ${ }^{77}$ The villages were clearly under the sway of the churches responsible for founding them. They were administered, insofar as there were community problems, by the minister who was their founder, or his successors. They were single-church communities, and single-school communities, which owed their existence to the church, and were morally and economically in debt to it. Cumper has even collected evidence that the churches played an important judiciary role in the villages they founded. ${ }^{48} \mathrm{It}$ is no wonder, then, as Cumper has pointed out, that while the planters referred derisively to Rev. Knibb, the outstanding leader of the Baptist missionary movement in Jamaica and a founder of many free villages, as 'King Knibb', his followers used the same term of reference with pride.

\section{CONCLUSION}

The peasantry of Jamaica in its majority came into being in the period immediately following Emancipation. Though the basic requirements for attaining the status of peasants were in the hands of the Jamaican freedmen themselves, executive leadership and, to some extent, capital, were provided through the missionary churches in a great number of cases. Under the stimulus of church leadership, there arose in the mountainous interior of the island large numbers of church-founded free villages. The sociology of these villages may have distinguished them from other free villages in Jamaica, and the fact that they were established by missionary churches signified that their populations would likewise be distinctive from the freedman population as a whole. Given the character of the church-founded free village, it may be justifiable to suppose that the Baptist peasant had a life-way at least initially differentiated from that of the peasants not involved in intimate association with a church group. The characteristics of this imputed distinctiveness might be elaborated by considering the sociological features already attributed to the church-founded free village as a community type. They would include a greater responsiveness to community pressure; a heightened concern with respectability; a stronger interest in literacy, social and economic advancement, and 'toeing the line'; and, it might be supposed, a greater respect for 'law and order', duly constituted authority, and persons 


\section{JAMAICAN CHURCH-FOUNDED FREE VILLAGE SYSTEM 65}

having high ascribed status. To some extent, as Cumper has suggested, it was in this context that the minister became a substitute - an altogether preferable substitute - for the estate owner, the overseer, the slave 'driver', the judge, and the custos. In terms of the establishment of a free peasantry in Jamaica, this shift in authority and leadership was of crucial importance; stress has been laid in this paper upon the significance of the missionary leaders in creating and perpetuating peasant communities. Yet there is a real possibility that the free villages are to this day characterized by a special sociology, and perhaps by a distinctive channeling of locally developed initiative along single lines of endeavor, due to their special social and religious character. It is suggested here that the history of local communities in a country such as Jamaica can still be reconstructed, at times in considerable detail, and that such reconstructions can prove valuable in understanding the social organization of the contemporary communities themselves. For both practical and intellectual reasons, the teasing out of the history of the rise of Caribbean peasantries is a useful task for the problem-oriented social scientist.

\section{NOTES}

I ERIC R. Wolf, Types of Latin American Peasantry: A Preliminary Discussion, A merican Anthropologist 57, No. 3, 1955, p. 452-47I.

2 Philip M. Sherlock, 'Editorial Note', Caribbean Quarterly 3, No. I, n.d., p. 3.

3 See, e.g., James G. Leyburn, The Haitian People (New Haven: Yale University Press), 1941, p. 32-87; GeORgES SEJOURNE, Etablissement de la propriété de la famille au lendemain de l'indépendance, Revue de la société d'histoire et de géographie d'Haïti, 6, No. 17, 1935, p. 9-22; Hugh PAGET, The Free Village System in Jamaica, Caribbean Quarterly, $I$, No. 4, n.d., p. 7-19.

4 George Cumper, Labour Demand and Supply in the Jamaican Sugar Industry, 1830-1850, Social and Economic Studies, 2, No. 4, 1954, p. 37-86.

5 Ibid, p. 39.

6 Quoted in Sidney, Lord Olivier, Jamaica, The Blessed Island (London: Faber and Faber), 1936, p. ro9.

7 An excellent discussion of planter ideology is given in PHILIP E. Curtin, Two Jamaicas (Cambridge: Harvard University Press), 1955.

8 The best example of planter political power in that period was the ejectment legislation empowering estate owners to charge exorbitant rents for the housing of resident freedmen. In some bizarre instances, estate owners actually attempted to charge families rent pro-rated for each family member! Cf. LeONARD TUCKER, Glorious Liberty (London: Baptist Missionary Society), 1914, p. 40.

West-Indische Gids XXXVIII 
9. George E. Cumper, A Modern Jamaican Sugar Estate, Soc. Econ. Studies 3, No. 2, 1954, p. 135. Also cf. Olivier, op. cit., p. 132-33.

ro Amy K. Lopez, Land and Labour to I900, Jamaican Historical Review $I$, 1948, p. 289-301. Also cf. Douglas Hall, The Social and Economic Background to Sugar in Slave Days, Caribbean Historical Review, Nos. 3-4, 1954, p. I6I-162.

II Sidney W. Mintz, The Jamaican Internal Marketing Pattern: Some Notes and Hypotheses, Soc. Econ. Studies 4, No. I, I955, p. 95-103. That both subsistence agriculture and marketing, which became so vital to a successful adaptation to peasant life after Emancipation, should have been compulsory under slavery, is reminiscent of a famous quotation: "There is something in human history like retribution; and it is a rule of historical retribution that its instrument be forged not by the offended, but by the offender himself". KARL Marx, The Indian Revolt, New York Tribune, Sept. I6, I857.

12 Olivier, op. cit., p. I59.

13 HaLl, op. cit., p. 16I-162.

I4 OlIVIER, op. cit., p. 133, I4I-142.

I5 Ernest A. PAyne, Freedom in Jamaica (London: Cary Press), I933, p. 60.

I6 PAgeT, op. cit. The creation of villages or communities of new peasants, rather than the random growth of scattered peasant homesteads, was not unique to post-Emancipation Jamaica. cf., for instance, Rawle FARLEy, The Rise of the Village Settlements of British Guiana, Car. Quart. 3, No. 2, 1953, p. Ior-109. These instances modify Wolf's statement concerning peasant settlement on 'recidual hits'. and suggest a more ordered and determinate process of economic and social change.

17 Most of the information on Rev. John Clark comes from Rev. George E. Henderson, Goodness and Mercy (Kingston), 1931. A copy of this work was given to the writer by Rev. and Mrs. John Bee of the Baptist Church, Brown's Town, St. Ann, Jamaica. The writer is deeply indebted to Rev. and Mrs.. Bee for their hospitality and many kindnesses. In their relationships with their parishioners, these religious leaders exemplify the ideals of their predecessors in Jamaica.

18 Rev. JoHN Clark, A Brief Account of the settlements of the emancipated peasantry in the neighbourhood of Brown's Town, Jamaica, in a letter from John Clark, missionary, to Joseph Sturge of Birmingham (Birmingham), $185^{2}$.

19 Olivier, op cit., p. II5.

20 EdWARD B. Underhill, The West Indies: Their Social and Religious Condition (London: Jackson, Walford and Hodder), 1861, p. 328.

21 KNIBB, cited in UNDERHILL, ibid.

22 Clark, not essaying a complete list, mentions Sturge Town (Birmingham), Clarksonville, Wilberforce, Stepney, Buxton, Bethany, Salem, Philadelphia, Goshen, Providence, Harmony, Happy Valley, Standfast, Liberty Valley, Homerton, Highbury, Claremont, Green Hill, Long Hill, Thatchfield, and Keith, as newly founded free villages in the district. Of these, five were clearly founded under Clark's leadership: Sturge Town, Clarksonville, Wilberforce, Stepney 
JAMAICAN CHURCH-FOUNDED FREE VILLAGE SYSTEM 67

and Buxton. A sixth community, Mount Abyla, is elsewhere described as founded by Clark. I believe this to be the section of modern Brown's Town which still carries that name. If so, then there were at least six free villages begun under church sponsorship by Clark. All are readily identifiable in St. Ann Parish today.

23 Clark, cited in Olivier, op. cit., p. II3-II4. According to a communication from Dr. M. G. Smith, the purchase is recorded in Liber 826 , Folio 102 , in Vol, 18 of the Records of Land Purchases maintained in the Spanish Town Record Office. The purchase was consummated June 20, I839- a baseline for the founding of Sturge Town. The record states that 126 acres were bought for $£$ I, ooo from James Stewart of Trelawney Parish. The difference between Rev. Clark's figure and that given in the Records is not of particular importance. M. G. Smith suggests that the $£ 3$ oo difference may have represented the cost of the house which was converted into a schoolroom.

24 The writer was serving as director of the Yale Graduate Interdisciplinary Field Training Program at the time. He is indebted to the Ford Foundation and to Yale's Graduate Interdisciplinary Training Committee for the opportunity to work in Jamaica.

25 The term 'crawl' or 'crawle' is cognate with Portuguese curral, Spanish corral, and South African kraal. Now obsolete, it was the Jamaican term for a pen for swine or slaves.

26 The writer is very grateful for the help given him by the staff of the Jamaica Institute in examining documentary and map materials, and in providing him with a faithfully rendered copy of what appears to be the original Clark map of the Angwin Crawl property.

27 The writer is grateful to Mr. Odel Fleming and to the Government of Jamaica Department of Surveys for help in providing him with a copy of the cadastral section showing the Angwin Crawl-Sturge Town property.

28 All calculations of component areas have been made by the writer on the basis of planimeter readings. Readings were taken for all component holdings on the Clark map, and for the entire holding as well, using 126 acres as the figure for total acreage. The writer is indebted to Professor Edward S. Deevey of the Department of Zoology, Yale University, for assistance in the use of that Department's planimeter.

29 Ideally, we should be able eventually to superimpose the Clark original map upon a map of present holdings in the same circumscribed area, and to seek to trace changes in tenure over much of a period exceeding one hundred years. The following are the main facts derived from planimeter measurements of a tracing of the Clark map and its component parts. There are 73 numbered holdings. The boundary separating holding no, 60 from holding no. 63 is not drawn in on the Clark map. "There is one unnumbered holding (east of holding no. 44). I have treated holdings nos. 60 and 63 as separate units. Together they come to 2.20 acres; I assigned each an arbitrary size one-half of this (I.I acres), which happens to be very nearly the statistically most frequent holding size among the remaining $7 \mathbf{I}$ numbered holdings. Holding no. 44 ( 0.45 acres) and the unnumbered holding adjoining it ( $0.4^{\circ}$ acres) are probably to be interpreted as a 
single holding of 0.85 acres. No other single holding falls below 0.73 acres (no. 32), and it seems unlikely that there would be two separate holdings as small as 0.45 and 0.40 acres. Yet I have treated them as separate; the difference made by treating them together in my overall calculations would have been slight in any case. Planimeter calculations enabled me to get acreages for each of the component agricultural holdings, for the house plot area, and for the (then) unoccupied area east of the house plots, as well as for the total area. There are inevitable errors in my calculations of course, but I believe them to be slight. Each component holding was measured separately in square centimeters, and these figures were converted into acres and decimal parts of acres. Upon totalling all components, I arrived at the figure of $\mathbf{I} 26.90$ acres. I take the correct acreage to have been I26 acres. By subtracting the calculated size of the unoccupied area (I6.66 acres) and for the house plot area (II.54 acres) from I26.90 acres, I arrived at the figure of 98.70 acres for the land held in 74 holdings. Upon totalling the separately calculated sizes of each individual holding, I arrived again at the figure of 98.70 acres. My planimeter readings for the entire area (calculated twice, as for every single holding) were: 308.4 square centimeters; 308.3 square centimeters. By adding the individual readings for each component subarea in a separate calculation, I arrived at the total of $3 \mathbf{I I . 4}$ square centimeters. I averaged these differing totals, admittedly perpetuating some error thereby, and arrived at 309.9 square centimeters as the calculated total area. Upon dividing this figure by a conversion factor, 2.46 (which permitted direct conversion from square centimeters to acres), I arrived at an acreage figure of $\mathbf{2 5 . 9 7}$ acres, that is, within 0.03 acres of the known size of the total holding. Agricultural holdings range from 0.40 acres (the unnumbered plot) to 3.05 acres (nos. 1 and 16 ).

\begin{tabular}{l|c|c|c|c}
\hline Holding Sizes & $\begin{array}{c}\text { Number of } \\
\text { Holdings }\end{array}$ & $\begin{array}{c}\text { \% of Total } \\
\text { Number of } \\
\text { Holdings }\end{array}$ & $\begin{array}{c}\% \text { of Total Area } \\
\text { of Holdings } \\
\text { (98.70 acres) }\end{array}$ & $\begin{array}{c}\text { Range } \\
\text { in Size }\end{array}$ \\
\hline more than 3 & & & & \\
acres & 2 & 2.7 & 6.2 & $3.05-3.05$ \\
$2.5-2.99$ acres & I & I.4 & 2.6 & 2.64 \\
$2.0-2.5$ acres & 9 & I2.2 & 20.2 & $2.07-2.40$ \\
I.5-I.99 acres & 4 & 5.4 & 6.9 & $1.58-1.91$ \\
I.O-I.49 acres & 47 & 63.5 & 54.9 & I.02-1.45 \\
less than I.0 & II & I4.8 & 9.1 & 0.40-0.98 \\
acre & 74 & I00.0 & 99.9 &
\end{tabular}

30 Clark indicates (Olivier, op. cit., p. II5) that current prices for settlers' land in St. Ann ranged from $£ 3$ to $£ \mathbf{I} 2$ per acre. If the $£$ rooo purchase price in the Records of Land Purchases (cf. note 23) is for land alone, this would raise the price per acre for settlers to approximately $£ 8$. 


\section{JAMAICAN CHURCH-FOUNDED FREE VILLAGE SYSTEM 69}

3 I Dr. M. G. Smith argues that continuing financial control was probably of minor importance, since more than half of the cost of Sturge Town was paid off immediately by the settlers. The point is certainly debatable, and will continue to be so, unless detailed records of local church relationships to the free villages can be recovered.

32 Clark, op. cit., p. 8.

33 Cited in Olivier, op. cit., p. II4.

34 ClaRK, op. cit., p II.

35 CuRTIN, op. cit., p. 28-4r.

36 UNDERHILL, op. cit., p. 312-313.

37 It is a curious fact that nowhere is the precise founding date of Sturge Town indicated. Henderson (op. cit., p. 79) states the school and church in Sturge Town were opened in 1840 . It seems fairly certain that the community was created in 1839 (cf. note 23 ).

$3^{8}$ The quantity of published and unpublished materials by missionaries and visitors on the Jamaican free villages is enormous, and very widely scattered. Other reports on Sturge Town may exist which have never come to the writer's attention.

39 CUMPER, op. cit. (cf. note 9) p. II9-I60.

40 Yehudi A. Cohen, "Interpersonal Relations in a Jamaican Community", Ph. D. thesis, Dept. of Anthropology, Yale University, I953.

4 I M. G. Sмrтн, Community organization in rural Jamaica, Soc. Econ. Studies 5, No. 3, 1956, p. 295-312.

42 Both M. G. Smith and Mr. Donald Hogg have pointed out to the writer the risk of assuming that church-founded free villages were more likely to be isolated geographically than those which grew without church support. It is conceivable, as Hogg has suggested, that the crucial factor in community differentiation in this instance may be isolation, in which case isolated free villages, whether or not founded by the churches, might be sociologically distinctive, even today. Yet another distinction, noted by Cumper, M. G. Smith, and Douglas Hall, is between the Jamaican mountainous interior and the coastal plains, and the effects of the related ecological and economic differences upon free village character. All of these variables - hill vs. plain, church-organized vs. non-church-organized, and isolated vs. non-isolated - admittedly need much more elaboration.

43 Cumper, op. cit., 1954, p. 137.

44 SмIтн, op. cit., p. 298.

45 The author is emphatically not claiming that church adherence is or was a precondition for economic and social assistance in Sturge Town. But it seems likely that faithful church-going improves one's standing in the community, and accordingly may increase one's economic opportunities.

46 The writer failed to get-adequate information concerning the competing Tabernacle church in Sturge Town. This is another gap in the data which can only be filled by further field work.

47 No effort has been made here to indicate the possible utility of considering the Jamaican church-founded free village community as a special type insofar as planned change programs in Jamaica are concerned. The rural population of Jamaica is not culturally homo- 
70 JAMAICAN CHURCH-FOUNDED FREE VILLAGE SYSTEM

geneous, nor are Jamaican rural communities to be regarded as uniform in social organization or in accessibility to change from outside. If the Jamaican church-founded free village constitutes a distinctive community type even today, then certainly the introduction of change in such a community will succeed best if the sociology of this community type is fully understood. The importance of understanding community variation and its implications for social change in Jamaica has been strikingly demonstrated in a recent study. Cf. William H. Davenport, "A comparative study of two Jamaican fishing communities", Ph. D. thesis, Dept. of Anthropology, Yale University, 1956.

48 Cumper, op. cit., 1954, p. 136. 